\title{
Petroleum Source Rock Properties of the Neogene Bhuban Shales, Bengal Basin, Bangladesh
}

(Pencirian Punca Batuan Petroleum di Syal Neogene Bhuban, Lembangan Bengal, Bangladesh)

\author{
MD. FARHADUZZAMAN*, WAN HASIAH ABDULlAH \& MD. AMINUl ISLAM
}

\begin{abstract}
The present study evaluates the petroleum source rock generation potential of the Neogene Bhuban shales from Bangladesh. Organic geochemical and organic petrological methods were used for analyzing 11 drill core samples from 4 gas fields in the basin. Source rock potential, maceral composition, organic matter abundance, biomarker distribution, thermal maturity, hydrocarbon generation and depositional environment were evaluated. Kerogen in the studied shale samples is classified mainly as Type III with lesser amounts of Type II. Vitrinite is the dominant maceral group observed in the analyzed Bhuban samples followed by liptinite and inertinite. Vitrinite reflectance, $T_{\max }$ and biomarker parameters indicate the thermal maturity ranges from just pre-oil window to mid-oil window. Based on its total organic carbon (TOC), extractable organic matter (EOM) and hydrogen index (HI), the analyzed Bhuban shales are ranked as mainly poor to fair source rocks but with good gas generation potential. The dominant terrestrial environment prevailed during the deposition of the studied Bhuban shales while the condition was sub-oxic as indicated by cross-plots of pristane versus phytane and sterane versus pristane/phytane ratios.
\end{abstract}

Keywords: Bengal Basin; Bhuban shale; hopane; hydrocarbon potential; sterane

\section{ABSTRAK}

Kajian ini membincangkan penilaian batuan punca bagi petroleum sampel syal Bhuban Neogene dari Bangladesh. Geokimia organik dan petrologi organik telah digunakan untuk menganalisis 11 sampel teras gerudi daripada 4 medan gas di kawasan tersebut. Potensi batuan punca, komposisi maseral, kedapatan bahan organik, taburan petanda biologi kematangan terma penjanaan hidrokarbon dan persekitaran pengenapan dinilai. Kerogen dalam sampel syal yang dikaji kebanyakannya dikelaskan sebagai Jenis III dengan jumlah Jenis II yang lebih kecil. Vitrinit adalah kumpulan maseral yang dominan dalam sampel Bhuban yang dianalisis diikuti oleh liptinit dan inertinit. Pantulan vitrinit, $T_{\max }$ dan parameter bio penanda menunjukkan kematangan terma daripada hanya pra-minyak ke tingkap-minyak pertengahan. Berdasarkan data TOC, EOM dan HI, syal Bhuban yang dianalisis kebanyakannya dinilai sebagai miskin ke sederhana sebagai batuan sumber dengan potensi penjanaan gas yang baik. Persekitaran daratan dominan semasa pengenapan syal Bhuban dikaji manakala keadaan pengenapan adalah sub-oksik sebagaimana yang dicadangkan berdasarkan plot pristana melawan fitana dan sterana melawan nisbah pristanalfitana.

Kata kunci: Hopana; lembangan Bengal; potensi hidrokarbon; sterana, syal Bhuban

\section{INTRODUCTION}

The Bengal Basin covers the whole of Bangladesh and part of India. It is bordered with three sides by India and one small side (southeast) by Myanmar (Figure 1). The Bhuban is the most important geological unit of the Bengal Basin since majority of the discovered hydrocarbon resources of Bangladesh have been confirmed within this stratigraphic formation. It is believed that the Bhuban Formation is acting both as source rock (shale part) and reservoir rock (sandstone part) for the existing petroleum system of the Bengal Basin (Imam 2005). So far, there is no detail work published on organic geochemical and petrographical aspects of the Bhuban shales except Farhaduzzaman et al. (2014). Here, we present the data from both techniques: Organic geochemical and petrographical for Bhuban
Formation shales. We also draw some conclusions considering kerogen facies, thermal maturity, depositional conditions and hydrocarbon generation potential.

\section{GEOLOGICAL CONTEXT}

Bangladesh is situated in the northeastern part of south Asia. The first collision of the northward moving Indian Plate with the Eurasian Plate took place in Lower Eocene. Subsequent subduction led to the rising IndoBurman Orogeny. The later finally separated the Burmese basins in the east from the Bengal Basin in the west (Reimann 1993). The identified stratigraphic formations of the Deep Basin unit (study area) include (from bottom upward) Tura Sandstone (Paleocene), Sylhet Limestone (Middle Eocene), Kopili Shale (Upper Eocene), Jenum 


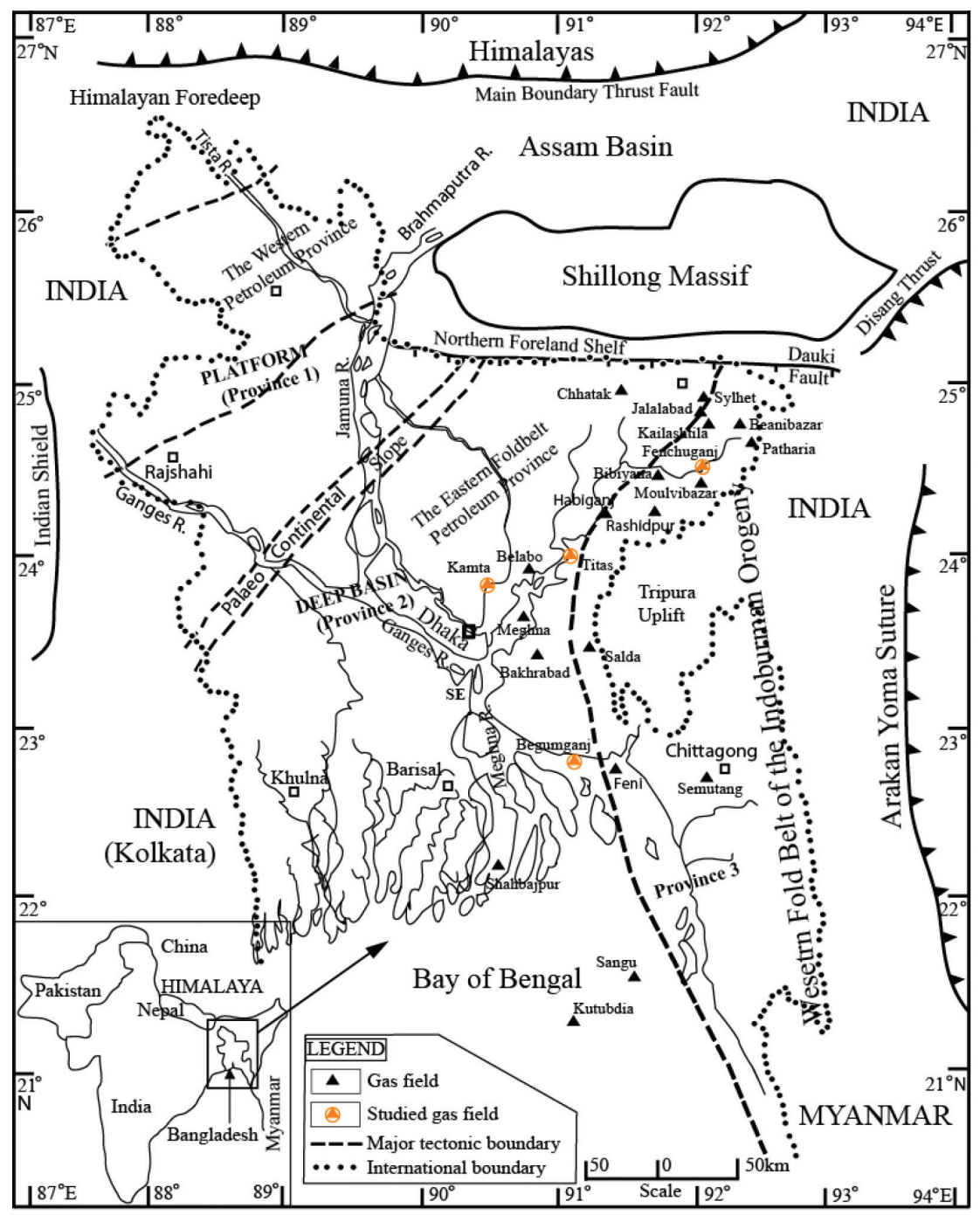

FIGURE 1. Location map of the study area showing major tectonic elements of the Bengal Basin (Farhaduzzaman et al. 2012a, 2013a, 2013c; Islam 2009; Reimann 1993)

(Oligocene), Renji (Oligocene), Bhuban (Miocene), Boka Bil (Early Pliocene), Tipam Sandstone (Middle Pliocene), Girujan Clay (Middle Pliocene), Dupi Tila (Late Pliocene), Madhupur Clay (Plio-Pleistocene) and Alluvium (Holocene) (Alam et al. 2003; Imam 2005). The studied unit is traditionally believed to have been deposited in a deltaic to shallow marine environment. Mostly all of the discovered gas and oil fields have been found within the Bhuban Formation of the Deep Basin unit. Estimated gas reserve (GIIP) in Bangladesh is 28.42 TCF with about 42 TCF undiscovered (Jamaluddin et al. 2001; Shamsuddin et al. 2004). Using 3D seismic survery (2011-2012), Petrobangla re-estimated the total recoverable oil reserves of 137 million barrels STOIIP.

\section{SAMPLES AND METHODS}

A total of eleven shale core samples of Bhuban Formation were collected from four different wells drilled of respective four gas fields (Fenchuganj, Titas, Kamta and
Begumganj) located in Deep Basin unit. The samples were crushed into fine powder and analyzed using a Weatherford Source Rock Analyzer (equivalent of RockEval equipment). Bitumen extraction was performed using Soxhlet apparatus and subsequently the extractable organic matter (EOM) was separated into aliphatic, aromatic and NSO fractions by column chromatographic techniques. The aliphatic hydrocarbon fractions were analyzed by gas chromatography (Agilent 6890N Series GC) and gas chromatography mass spectrometry (GCMS). The FID gas chromatograph with HP-5MS column, temperature programmed from 40 to $300^{\circ} \mathrm{C}$ at a rate of $4^{\circ} \mathrm{C} / \mathrm{min}$ and then held for $30 \mathrm{~min}$ at $300^{\circ} \mathrm{C}$, was used for $\mathrm{GC}$ analysis. GCMS experiments were performed on a V 5975B inert MSD mass spectrometer with a gas chromatograph attached directly to the ion source ( $70 \mathrm{eV}$ ionization voltage, $100 \mathrm{~mA}$ filament emissions current, $230^{\circ} \mathrm{C}$ interface temperature). For organic petrographical study, the samples were prepared by mounting whole rock fragments in resin blocks and polished to a highly reflecting surface using 
progressively finer alumina suspension (1, 0.3 and 0.05 $\mu \mathrm{m})$. Petrographical examination was carried out under oil immersion using a LEICA DM6000M microscope and CTR6000 photometry system equipped with fluorescence illuminators (ultraviolet light). Except for SRA from Weatherford (USA), all other analyses were carried out in the UM Geology Department, Malaysia.

\section{RESULTS AND DISCUSSION}

\section{SOURCE ROCK PROPERTIES}

The results obtained from Source Rock Analyzer (SRA) are shown in Table 1. All samples were organic lean $(<1 \%)$ and hydrogen index (HI) values of Bhuban Formation range from 39 to $232 \mathrm{mg} \mathrm{HC} / \mathrm{g}$ TOC. Most samples were plotted in the Type III range but one sample plotted within Type II band which implies an organic matter mixture of kerogen types (III/II) (Figure 2). The oxygen index (OI) varies from 64 to $168 \mathrm{mg} \mathrm{CO}_{2} / \mathrm{g}$ TOC and the cross-plot of HI versus OI (modified van Krevelen diagram; not shown here) showed mostly Type III character. $\mathrm{T}_{\max }$ values vary from 429 to $441^{\circ} \mathrm{C}$ and the mean vitrinite reflectance value ranges from 0.57 to $0.71\left(\% \mathrm{R}_{\mathrm{o}}\right)$ for the studied shales. The source rock potential of the analyzed Bhuban Formation shales was evaluated as mostly poor to fair based on classification of Peters and Cassa (1994).

\section{MACERAL COMPOSITION}

Vitrinite (60-80 vol.\%) is the dominant maceral group found in the analyzed Bhuban shales followed by liptinite (20-25 vol.\%) and inertinite (8-15 vol.\%). The important liptinitic macerals include sporinite, cutinite, resinite, amorphous organic matter, liptodetrinite and alginite (trace amount). The significant presence of these liptinitic macerals along with the solid bitumen (staining) contribute a minor oil-prone character to the dominantly vitrinitic assemblages (Figure 3).

\section{EXTRACTABLE ORGANIC MATTER AND BIOMARKER CHARACTERISTICS}

The total soluble extract varies from 132 to 2814 ppm in the analyzed samples. The concentration of aromatic hydrocarbons (57-548 ppm) is higher than that of aliphatic hydrocarbons (9-300 ppm) in the studied shales. The total soluble hydrocarbon yield ranges from 21 to $139 \mathrm{mg}$ $\mathrm{HC} / \mathrm{g}$ TOC. The TIC (total ion current), m/z 191 and 217 chromatograms of the analyzed aliphatic fractions were used for interpretation and biomarker distributions (Figure 4). The unimodal distributions of n-alkanes from $C_{10}$ to $C_{35}$ with the maxima standing at $\mathrm{C}_{16}$ (mostly) or $\mathrm{C}_{18}$ have been observed in the gas chromatograms of the analyzed Bhuban shale samples (Figure 4(a)). The calculated CPI values are close to unity from 0.99 to 1.37 in Bhuban shales. In most of the analyzed samples, the odd carbon homologs dominate over the even carbon homologs. Nonetheless, even carbon homologs dominate over the odd carbon homologs in a few samples. The pristane/phytane ratio is low to fairly high and it varies from 0.99 to 3.74 .

The $\mathrm{C}_{30} \alpha \beta$-hopane is the dominant member of the abundant pentacyclic triterpanes (hopanes and moretanes) in all the analyzed Bhuban shale samples (Figure 4(b) and 4(c)). Homohopanes are lower in concentration and dominated by $\mathrm{C}_{31}$-hopane in the studied samples. The $\mathrm{S}$-isomers are dominant over R-isomers in some of the analyzed samples (Figure 4(b)) which indicate the samples are thermally mature for hydrocarbon generation. On the other hand, $\mathrm{R}$-isomers are dominant over the $\mathrm{S}$-isomers among the homohopanes $\left(\mathrm{C}_{31}-\mathrm{C}_{33}\right)$ for a few of the analyzed samples which indicate the samples are thermally immature for hydrocarbon generation (Figure $4(c))$. In general, $\alpha \beta$-hopanes are more dominant than the $\beta \alpha$-hopanes (moretanes). The Ts/Tm ratio of the studied samples ranges from 0.26 to $0.87 . \mathrm{C}_{30}$ moretane $/ \mathrm{C}_{30}$ hopane and $\mathrm{C}_{32} 22 \mathrm{~S} /(22 \mathrm{~S}+22 \mathrm{R})$ ranges from 0.09 to 0.44 and 0.47 to 0.63 , respectively, for the analyzed Bhuban Formation shales. Considerable abundances of $18 \alpha(\mathrm{H})$-oleanane (higher plant marker) have been found in all the studied samples. $\mathrm{C}_{29}$ sterane is the most dominant component in the $\mathrm{m} / \mathrm{z} 217$ mass fragmentograms which are dominated by regular steranes compared to diasteranes (Figure 4(d)). The most commonly used sterane parameters include $\mathrm{C}_{29}$ sterane, $\mathrm{C}_{27} /\left(\mathrm{C}_{27}+\mathrm{C}_{29}\right)$ sterane and diasterane/sterane ratios and these values range from 36 to $64 \%, 0.21$ to 0.48 and 0.05 to 0.42 , respectively, in the analyzed Bhuban samples.

\section{THERMAL MATURITY}

Thermally immature to mature oil window has been appraised for the investigated Bhuban Formation shales as evidenced by randomly measured mean vitrinite reflectance and $\mathrm{T}_{\max }$ values. The randomly measured vitrinite reflectance value ranges from 0.57 to $0.71\left(\% \mathrm{R}_{\mathrm{o}}\right)$ in the analyzed Bhuban samples. It implies that the thermal maturity of the analyzed shale samples varies from just pre-oil window to mid-oil window thermogenic condition for hydrocarbon generation (Peters \& Cassa 1994). The $\mathrm{T}_{\max }$ value obtained from SRA ranges from 429 to $441^{\circ} \mathrm{C}$ indicates the studied Bhuban samples are of thermally immature to mature for oil generation which is in a good agreement with the interpretation based on vitrinite reflectance values. The recorded production index (PI) value ranges from 0.17 to 0.25 in the analyzed shales and it also suggests the immature to mature oil window condition (Peters \& Cassa 1994).

The $\mathrm{C}_{32}$-homohopanes ratio $(22 \mathrm{~S} /(22 \mathrm{~S}+22 \mathrm{R}))$ rises from 0 to about 0.65 while 0.57 to 0.62 is the equilibrium range commonly observed during maturation (Seifert \& Moldowan 1986). The calculated ratio values of $0.47-0.63$ for the studied Bhuban samples fall within and outside the equilibrium range. It is thus demonstrating the thermal maturity condition has been reached partially, i.e., it represents immature to mature oil window. The calculated $\mathrm{C}_{30}$-moretane $/ \mathrm{C}_{30}$-hopane ratio of the studied Bhuban 


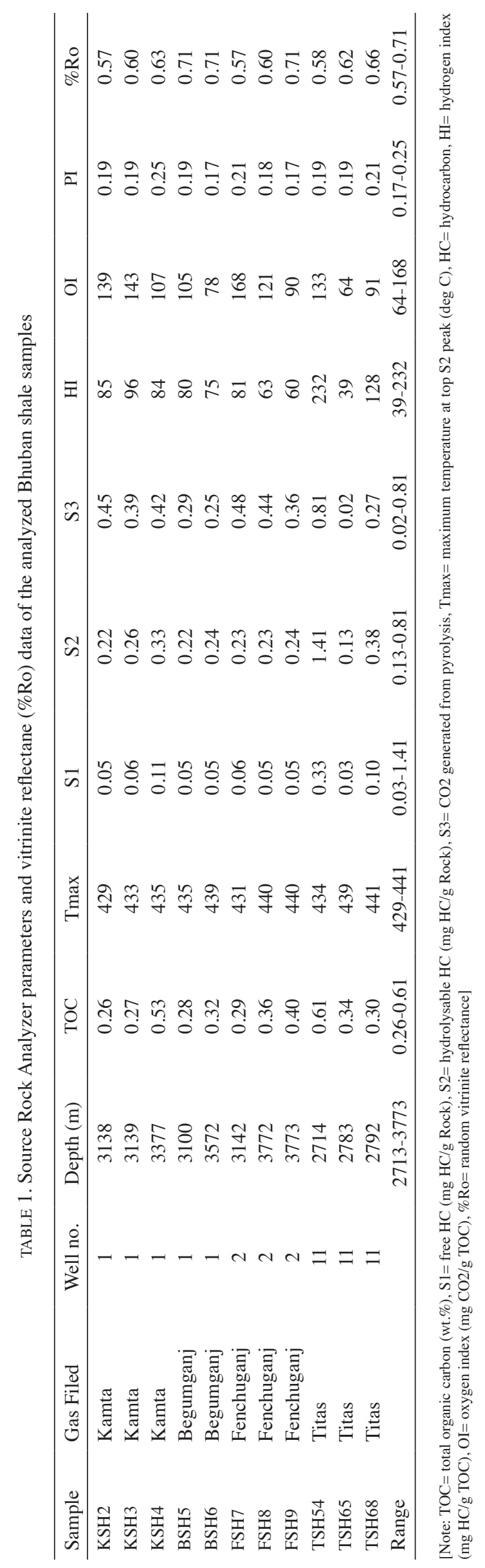




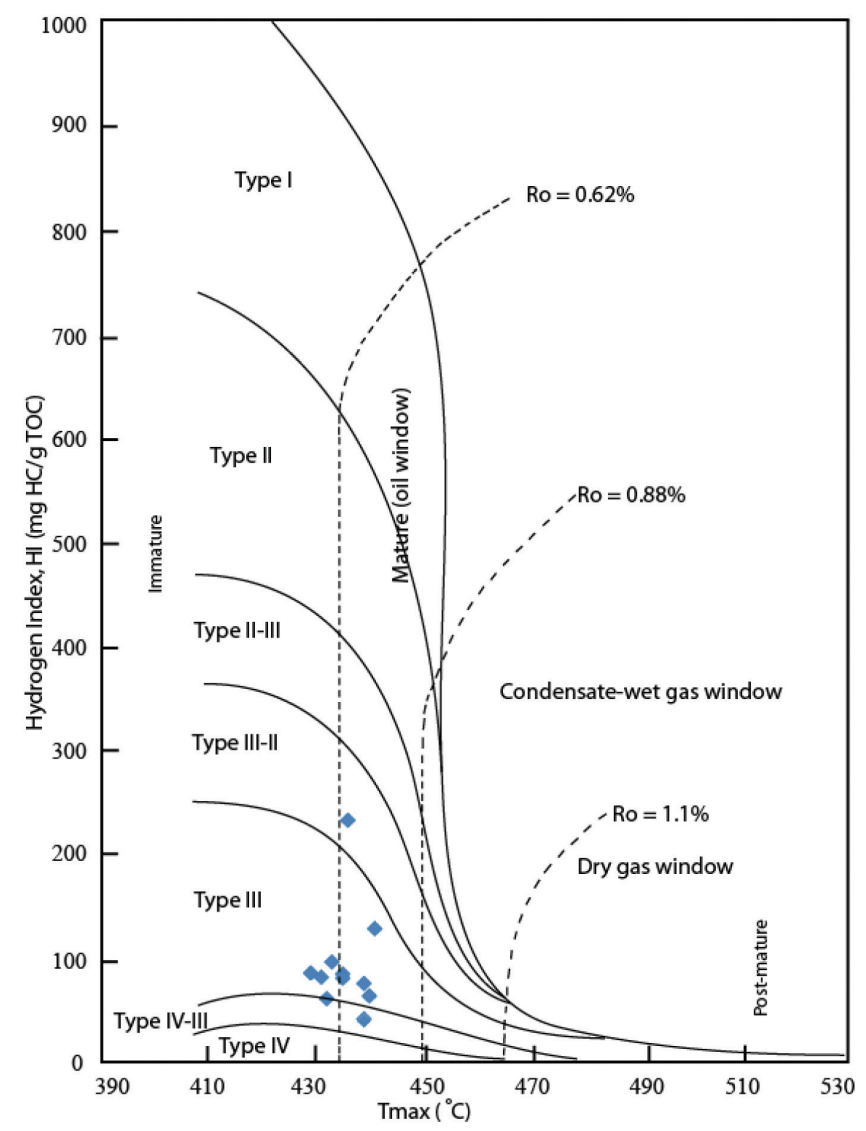

FIGURE 2. Cross-plot of hydrogen index vs $\mathrm{T}_{\max }$ indicates the analyzed samples are mostly of Type

III kerogen. The organic matters are of mainly thermally immature to mature for hydrocarbon generation (Farhaduzzaman et al. 2013b; Koeverden et al. 2011)
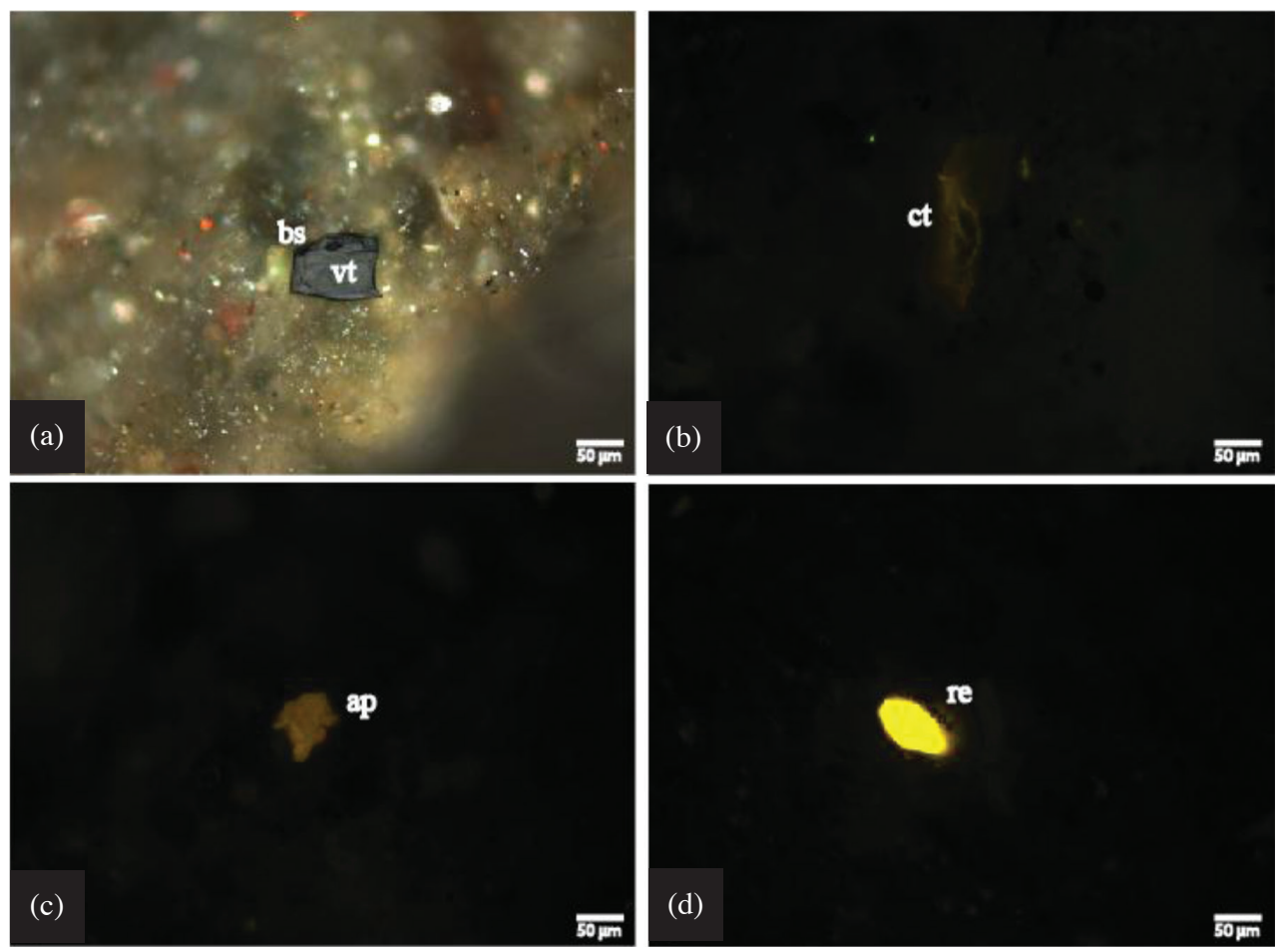

FIGURE 3. Photomicrographs of the analyzed Bhuban shale samples. (a) Common occurrence of Type III kerogen represented by grey vitrinite (vt) maceral, depth $3377 \mathrm{~m}$ of the well Kamta 1, (b) Type II kerogen represented by brownish thin cutinite (ct) maceral, depth $2792 \mathrm{~m}$ of the well Titas 11, (c) Type II kerogen represented by brownish amorphous materials (ap), depth $3100 \mathrm{~m}$ of the well Begumganj 1 and (d) Type II kerogen represented by bright yellow color resinite (re) maceral, depth $3773 \mathrm{~m}$ of the well Fenchuganj 2 [Photomicrograph (a) is taken under normal reflected white light while others are under ultraviolet light] 


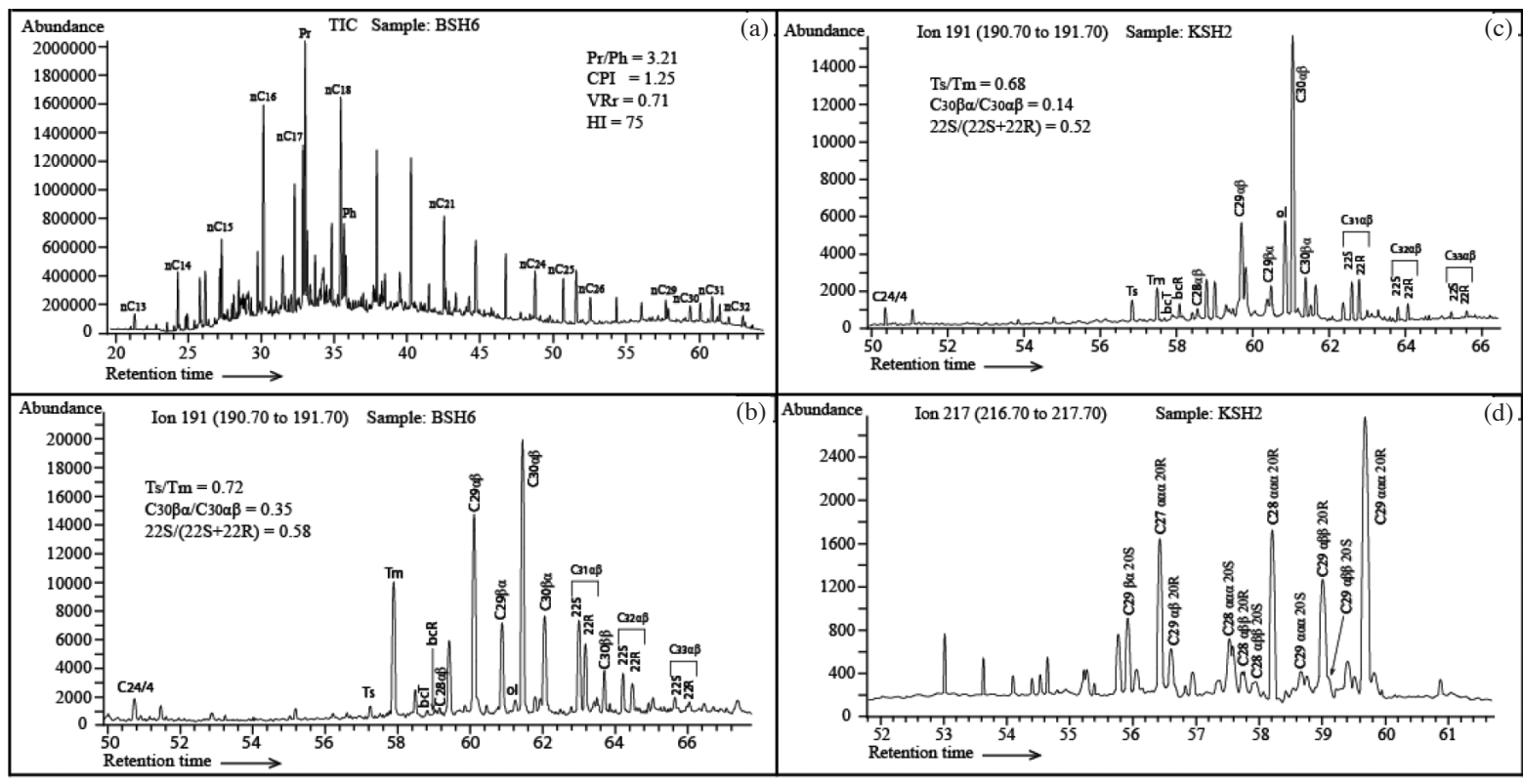

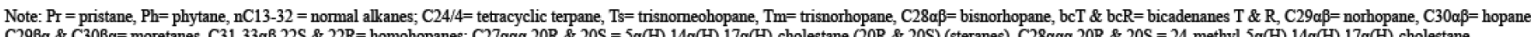

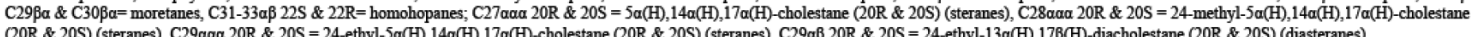

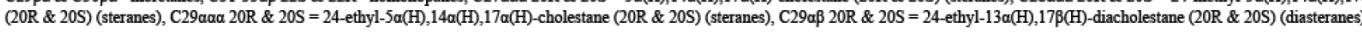

FIGURE 4. (a) The total ion current (TIC) of a studied sample (BSH6) which displays unimodal distribution in the n-alkane members, (b) An example of a m/z 191 mass fragmentogram of a mature sample (BSH6), (c) An example of a m/z 191 mass fragmentogram of an immature sample (KSH2), (d) The $\mathrm{m} / \mathrm{z} 217$ mass fragmentogram of the studied sample (KSH2) showing the dominance of $\mathrm{C}_{29}$ regular sterane compared to $\mathrm{C}_{27}$ or $\mathrm{C}_{28}$ steranes

shales varies from 0.09 to 0.44 which correspond again to the range of immature-mature thermal maturity condition (Mackenzie et al. 1980). Nonetheless, the solid bitumen or bitumen stain is considered as 'free' or expelled heavy petroleum. This type of bitumen stain has been observed in the analyzed shale samples under the microscope and it also suggests the organic matter of the studied shales has already expelled hydrocarbon in parts within the associated petroleum system of the Bengal Basin, Bangladesh.

\section{HYDROCARBON GENERATION POTENTIAL}

The cross-plot of $\mathrm{T}_{\max }\left({ }^{\circ} \mathrm{C}\right)$ and production index (PI) depicts that the organic matter of the analyzed Bhuban shales have already started to generate hydrocarbon (Figure 5). This is supported by the earlier interpretation on the basis of vitrinite reflectance and $\mathrm{T}_{\max }$ values. The measured SRA $\mathrm{T}_{\max }$ of the analyzed shale samples varies from 429 to $441^{\circ} \mathrm{C}$ while the hydrocarbon generation usually starts at the maturity level of $435^{\circ} \mathrm{C}$ (Peters \& Cassa 1994; Peters \& Moldowan 1993; Peters et al. 2005). The studied Bhuban shales with low to fair TOC (0.26-0.61\%), low to fair S2 values $(0.13-1.41 \mathrm{mg} \mathrm{HC} / \mathrm{g}$ TOC), low to moderate total extract yield (132-2814 $\mathrm{ppm})$, low to fair production index $(0.17-0.25)$, low to medium hydrocarbon yield (21-139 mg HC/g TOC) and the presence of common liptinitic materials suggested poor to fair potential for hydrocarbon generation. The mean vitrinite reflectance value ranged from 0.57 to $0.71\left(\% \mathrm{R}_{\mathrm{o}}\right)$ in the analyzed Bhuban shales (equilibrium value is 0.60 as stated by Philp 1985 and Peters \& Cassa

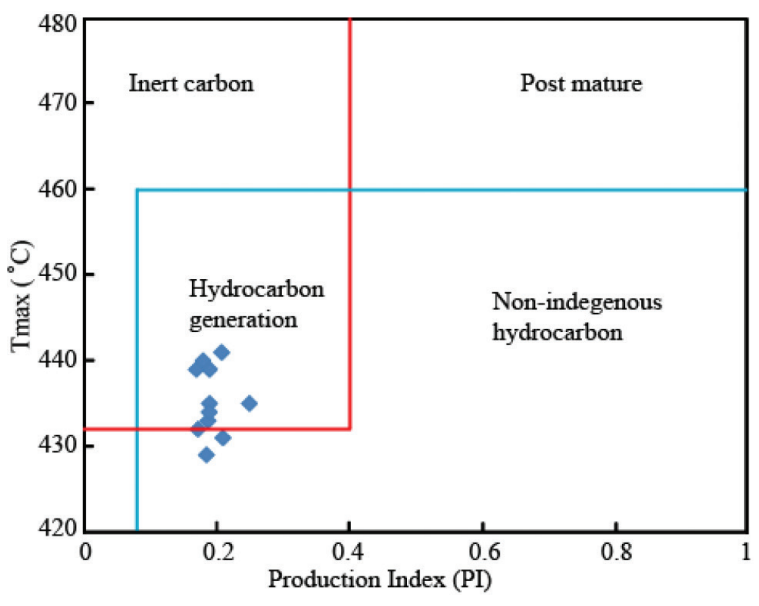

FIGURE 5. The cross-plot of $\mathrm{T}_{\max }$ and production index shows that the investigated Bhuban shale samples fall within and outside the petroleum generation zone (c.f. Farhaduzzaman et al. 2013b)

1994) again supports the organic matter of the analyzed samples have partially achieved the thermal maturity level for hydrocarbon generation. The dominancy of short chain n-alkanes $\left(\mathrm{C}_{16}-\mathrm{C}_{20}\right)$ in the gas chromatogram (TIC) of Bhuban Formation indicates the generation of light hydrocarbons together with some condensates. However, the liquid hydrocarbon potential of the analyzed shale samples is most likely attributed to the contents of liptinitic macerals. The entire petroleum discovery is natural gas with little amount of oil and condensate in the 
Bengal Basin, Bangladesh (Imam 2013). This is in good agreement with the present interpretation of hydrocarbon generation potential for the Bhuban Formation.

\section{DEPOSITIONAL ENVIRONMENT}

The depositional environment of shale and its condition of deposition is often considered as very complex (Wan Hasiah 1999). The modeled steranes triangular plot (Figure 6) indicates the analyzed Bhuban shales deposited mostly in terrestrial environmental setting with some marine inputs (Huang \& Meinschein 1979). The marine influence is also supported by the occurrence of oleanane (c.f., Murray et al. 1997). Diasterane abundances in comparison to regular steranes are often used to distinguish carbonate facies (low diasteranes) from clastic ones (Waples \& Machihara 1991). The noticeable presence of diasteranes compared to steranes of the studied shale samples characteristically supports the dominance of clastic depositional facies. The cross-plot of $\mathrm{Pr} / \mathrm{nC}_{17}$ versus $\mathrm{Ph} / \mathrm{nC} 18$ (Figure 7) based on the analyzed samples implies the source of the organic matter of Bhuban shales was mostly terrestrial-derived. The condition of deposition was an alternation of oxic to anoxic within a deltaic to shallow marine environment. This is supported by the cross-plot of $\mathrm{Pr} / \mathrm{Ph}$ versus $\mathrm{C}_{27} /$ $\left(\mathrm{C}_{27}+\mathrm{C}_{29}\right)$ sterane of the present study (Figure 8). This also indicates the dominant terrestrial environmental settings with oxic-anoxic depositional condition (Waseda \& Nishita 1998). Minor marine (pelagic) influence is also suggested by this diagram. The presence of bicadinanes in the gas chromatograms $(\mathrm{m} / \mathrm{z}$ 191) of the investigated Bhuban samples also supports this terrestrial depositional setting as previously reported by Pearson and Alam (1993).

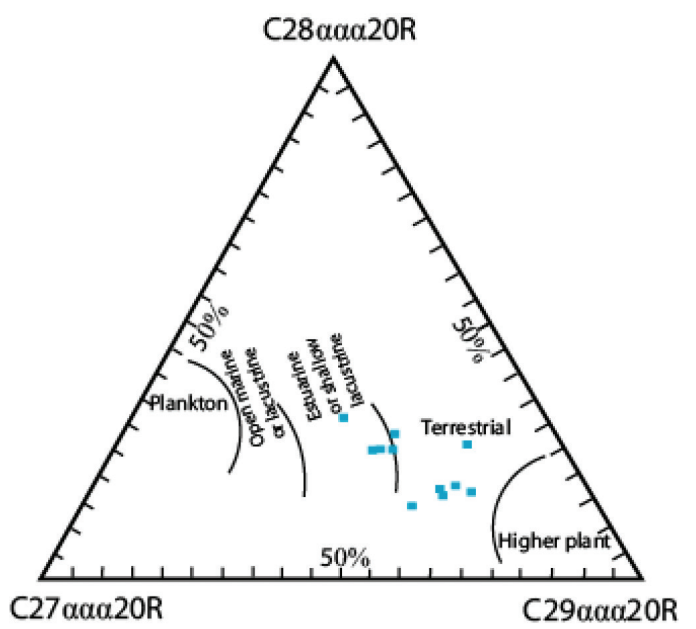

FIGURE 6. Relationship between sterane compositions, source input and depositional environment. The analyzed Bhuban shales are dominated by terrestrial organic matter input with minor contribution from marine sources (adopted after Waples \& Machihara 1991)

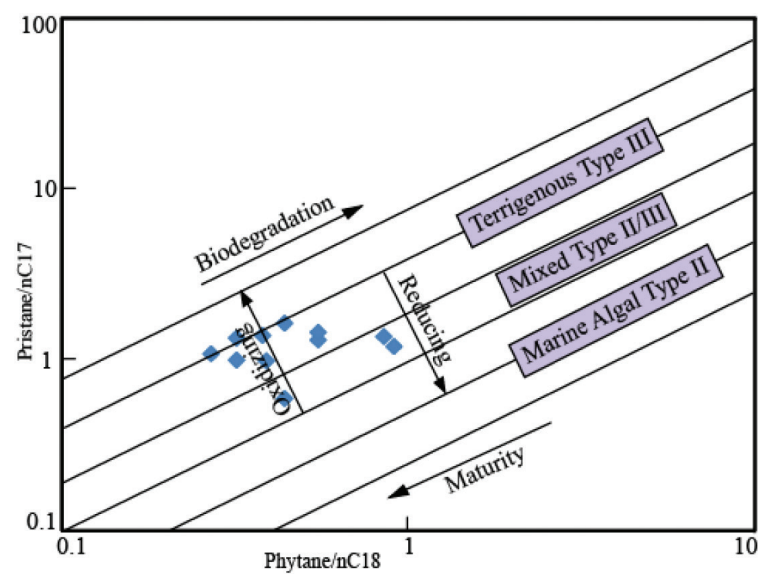

FIGURE 7. A plot of pristane $/ \mathrm{nC}_{17}$ versus Phytane $/ \mathrm{nC}_{18}$ of the examined samples indicates the condition of deposition for the analyzed samples. The analyzed Bhuban samples suggest a mixture of terrigenous Type III and II organic matter inputs deposited under oxic-anoxic condition (adopted after Peters et al. 2005)

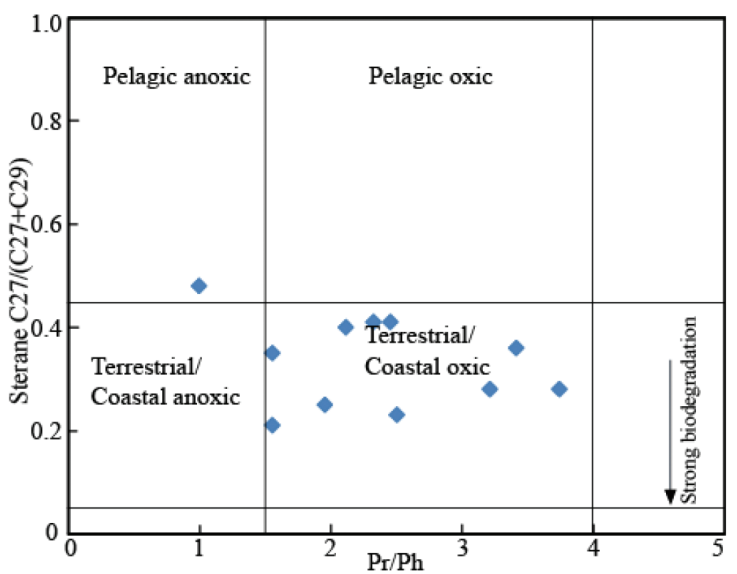

FIGURE 8. A cross-plot of $\mathrm{Pr} / \mathrm{Ph}$ and sterane $\mathrm{C}_{27} /\left(\mathrm{C}_{27}+\mathrm{C}_{29}\right)$ ratios indicates the analyzed Bhuban shales deposited within an oxicanoxic terrestrial environmental settings with minor influence from pelagic source (adopted after Waseda \& Nishita 1998)

The oxic condition of any terrestrial depositional environment has extensively been appraised by various authors considering the ratio of $\mathrm{Pr} / \mathrm{Ph}$ (Peters \& Moldowan 1993). The source rocks with $\mathrm{Pr} / \mathrm{Ph}$ ratio greater than 1 are more likely to have formed in an oxidizing environmental setting. Thus the $\mathrm{Pr} / \mathrm{Ph}$ ratio of the analyzed shales ranged from 0.99 to 3.41 indicates a predominant terrestrial environment. The condition of deposition was oxic. The terrestrial depositional environment is also supported by petrographic data such as dominating vitrinite macerals and the high abundance of woody fragments. The marine influence is suggested by the presence of liptinite macerals such as liptodetrinite and fluorescing amorphous organic matter. 


\section{CONCLUSION}

The investigated Bhuban shales consist of a mixture of Type III/II kerogens with Type III dominant. They were determined to be thermally immature to mature for hydrocarbon generation based on the mean vitrinite reflectance and $\mathrm{T}_{\max }$ values. The production index value and the biomarker parameters of $22 \mathrm{~S} /(22 \mathrm{~S}+22 \mathrm{R})$ hopane, moretane/hopane ratio and sterane data have also supported this level of thermal maturity. SRA and biomarkers data concludes that the analyzed Bhuban shales of the Bengal Basin (Bangladesh) possess poor to fair quality source potential for hydrocarbon generation. The depositional environment is evaluated as dominantly terrestrial setting with minor marine influences. The condition of deposition was an alternation of oxic-anoxic.

\section{ACKNOWLEDGEMENTS}

The authors are grateful to Dr. Hussain Monsur, Chairman of PETROBANGLA for supplying the data/samples for current research. The first author cordially appreciated the cooperation and motivation provided by Prof. Khalil R. Chowdhury and his colleagues at the Jahangirnagar University. The management of Sylhet Gas Fields Ltd, PETROBANGLA deserves cordial thanks for the official support to this research (M.F.). The authors are also thankful to two anonymous referees for their fruitful remarks while reviewing. The authors also acknowledge the Bright Sparks Fellowship BSP-APP-1080-2012 and grants PV100-2011A, RG145-11AFR and FP042-2013A of University Malaya for the financial supports.

\section{REFERENCES}

Alam, M., Alam, M.M., Curray, J.R., Chowdhury, M.L.R. \& Gani, M.R. 2003. An overview of the sedimentary geology of the Bengal Basin in relation to the regional tectonic framework and basin-fill history. Sedimentary Geology 155(3-4): 179-208.

Farhaduzzaman, M., Wan Hasiah, A. \& Islam, M.A. 2014. Hydrocarbon source potential and depositional environment of the Surma Group shales of Bengal Basin, Bangladesh. Journal of the Geological Society of India 83(4): 433-446.

Farhaduzzaman, M., Wan Hasiah, A. \& Islam, M.A. 2013a. Petrographic characteristics and paleoenvironments of the Permian coal resources of the Barapukuria and Dighipara Basins, Bangladesh. Journal of Asian Earth Sciences 64: 272-287.

Farhaduzzaman, M., Wan Hasiah, A., Islam, M.A. \& Pearson, M.J. 2013b. Organic facies variations and hydrocarbon generation potential of the Permian coals and related sediments, Barapukuria and Dighipara Basins, NW Bangladesh. Journal of Petroleum Geology 36(2): 117-138.

Farhaduzzaman, M., Wan Hasiah, A. \& Islam, M.A. 2013c. Organic geochemical and petrological evaluation of the Early Pliocene Boka Bil shales of the Bengal Basin, Bangladesh. Malaysian Journal of Science (under review).

Farhaduzzaman, M., Wan Hasiah, A. \& Islam, M.A. 2012a. Depositional environment and hydrocarbon source potential of the Permian Gondwana coals from the Barapukuria
Basin, Northwest Bangladesh. International Journal of Coal Geology 90-91: 162-179.

Huang, W.Y. \& Meinschein, W.G. 1979. Sterols as ecological indicators. Geochimica et Cosmochimica Acta 43(5): 739745 .

Imam, B. 2013. Energy Resources of Bangladesh 2nd ed. University Grants Commission, Dhaka.

Islam, M.A. 2009. Diagenesis and reservoir quality of Bhuban sandstones (Neogene), Titas Gas Field, Bengal Basin, Bangladesh. Journal of Asian Earth Sciences 35(1): 89-100.

Jamaluddin, M., Nasrin, N., Rahman, M., Anwara, H. \& Bygdevold, J. 2001. Bangladesh petroleum potential and resource assessment 2001. HCU-NPD, Dhaka.

Koeverden, J.H., Karlsen, D.A. \& Backer-Owe, K. 2011. Carboniferous non-marine source rocks from Spitsbergen and Bjørnøya: Comparison with the Western Arctic. Journal of Petroleum Geology 34(1): 53-66.

Mackenzie, A.S., Patience, R.L., Maxwell, J.R., Vandenbroucke, M. \& Durand, B. 1980. Molecular parameters of maturation in the Toarcian shales, Paris Basin. Changes in the configurations of acyclic isoprenoid alkanes, steranes and triterpanes. Geochimica et Cosmochimica Acta 44(11): 1709-1721.

Murray, A.P., Sosrowidjojo, I.B., Alexander, R., Kagi, R.I., Norgate, C.M. \& Summons, R.E. 1997. Oleananes in oils and sediments: Evidence of marine influence during early diagenesis? Geochimica et Cosmochimica Acta 61(6):12611276.

Pearson, M.J. \& Alam, M. 1993. Bicadinanes and other terrestrial terpenoids in immature Oligocene sedimentary rocks and a related oil from the Surma Basin, N.E. Bangladesh. Organic Geochemistry 20(5): 539-554.

Peters, K.E. \& Cassa, M.R. 1994. Applied source rock geochemistry. In The Petroleum System-From Source to Trap, edited by Magoon, L.B. \& Dow, W.G. The American Association of Petroleum Geologists Memoir 60: 93-120.

Peters, K.E. \& Moldowan, J.M. 1993. The Biomarker GuideInterpreting Molecular Fossils in Petroleum and Ancient Sediments. New Jersey, Englewood Cliffs: Prentice-Hall Inc.

Peters, K.E., Walters, C.C. \& Moldowan, J.M. 2005. The Biomarker Guide-Biomarkers and Isotopes in the Environment and Human History. London: Cambridge University Press.

Philp, R.P. 1985. Fossil Fuel Biomarkers: Applications and Spectra. Amsterdam: Elsevier Science Publishers B.V.

Reimann, K.U. 1993. Geology of Bangladesh. Berlin-Stuttgart, Germany: Gebruder Borntraeger.

Seifert, W.K. \& Moldowan, J.M. 1986. Use of biological markers in petroleum exploration. In Biological Markers in the Sedimentary Record, edited by Johns, R.B. Amsterdam: Elsevier Science Publishers B.V.

Shamsuddin, A.K.M., Huq, M.M., Faruque, M.A., Chudhury, Z., Akhteruzzaman, M., Rahman, M., Haque, A., Talukder, M.W., Bygdevoll, J. \& Rafdal, J. 2004. Bangladesh gas reserve estimation 2003. HCU-NPD, Dhaka, Bangladesh.

Wan Hasiah, A. 1999. Organic facies variations in the Triassic shallow marine and deep marine shales of central Spitsbergen, Svalbard. Marine and Petroleum Geology 16(5): 467-481.

Waples, D.W. \& Machihara, T. 1991. Biomarkers for Geologists: A practical guide to the application of Steranes and Triterpanes in petroleum geology. The AAPG Methods in Exploration Series 9, Tulsa. 
Waseda, A. \& Nishita, H. 1998. Geochemical characteristics of terrigenous- and marine-sourced oils in Hokkaido, Japan. Organic Geochemistry 28(1-2): 27-41.

Md. Farhaduzzaman* \& Wan Hasiah Abdullah Department of Geology, Faculty of Science University of Malaya

50603 Kuala Lumpur

Malaysia
Md. Aminul Islam

Department of Petroleum Geoscience, Faculty of Science

Universiti Brunei Darussalam, Gadong BE1410

Brunei Darussalam

*Corresponding author; email: farhad.geo@siswa.um.edu.my

Received: 10 June 2013

Accepted: 18 November 2014 